O. Yu. Khetselius, A. V. Glushkov, S. N. Stepanenko, A. A. Svinarenko, Yu. Ya. Bunyakova, E. T. Vitovskaya

\author{
Odessa State Environmental University, L'vovskaya str.15, Odessa-9, 65016, Ukraine \\ E-mail: okhetsel@gmail.com
}

\title{
ADVANCED PHOTOCHEMICAL BOX AND QUANTUM-KINETIC MODELS FOR SENSING ENERGY, RADIATION EXCHANGE IN ATMOSPHERIC GASES MIXTURES AND LASER- MOLECULES INTERACTION
}

\begin{abstract}
The aim of the work is to develop a set of optimal photochemical models with the inclusion of a submodel of the boundary layer using complex plane field methods and spectral algorithms and optimized blocks describing nonlinear radiation transfer and chemical conversion mechanisms, quantum-kinetic and photoelectronic models for describing nonlinear optical effects due to the interaction of infrared laser radiation with the gas atmosphere of an industrial city. An obvious consequence of the resonant interaction (in particular, absorption) of electromagnetic radiation by atmospheric molecular gases is a quantitative redistribution of molecules by energy levels of internal degrees of freedom, which quantitatively changes the so-called gas absorption coefficient. A change in the population levels of the gas mixture causes a violation of the thermodynamic equilibrium between the vibrations of the molecules and their translational motion and causes a new nonlinear effect of the photokinetic cooling of the atmospheric environment.
\end{abstract}

\section{Introduction}

At the present time laser systems for monitoring the environmental state of atmosphere have become widespread. The classical laser sensing methods is mainly based on the processes of linear interaction of radiation with the atmospheric gases and aerosol components of the atmosphere [1-10]. However, as it was shown in multiple investigations (c.g., $[1-5,9])$, there are a number of important problems and tasks, where the linear methods of sensing are ineffective both due to technical difficulties arising due to small interaction cross sections and because of fundamental physical limitations when these effects do not contain information about the desired medium parameters. First of all, speech is about such tasks as remote elemental analysis of condensed matter of aerosols and underlying surface, determination of heavy metals and inert gas atoms content, detection of ultra-low concentrations of gas impurities and substance vapors with selective absorption coefficients $\mathrm{cm}^{-1}$, and a number of other problems related, in particular, to diagnostics industrial pollution etc [1]. It is very important to remember about some fundamental aspects of the interaction of electromagnetic radiation with atoms and molecules of the atmospheric environment, especially in a case of the intense external field. Here it should be not- ed a nonlinear response of atoms and molecules . The obvious consequence of resonant interaction (in particular, absorption) of electromagnetic radiation (hereinafter, as a rule, will be coherent, that is, laser radiation) by molecular gases of the atmosphere is the quantitative redistribution of molecules by the energy levels of internal degrees of freedom. In turn, this will change the so-called gas absorption coefficient. Changing the population levels of the mixture of gases causes a disturbance of thermodynamic equilibrium between the vibrations of molecules and their translational motion, resulting in kinetic cooling of the environment.

According to [4], the industrial city's air quality and the formation of photochemical oxidants (of which ozone is a major component) involves the interaction of source emissions and a series of different quite complex physical and chemical processes. Ozone is formed in the atmosphere as a result of a complex series of thermal and photochemical reactions involving nitrogen oxides and reactive hydrocarbons. The known photochemical box model (PBM) by Jin-SchereDemerjian [4] includes three main blocks: (1) a boundary-layer submodel, (2) a revised radiative transfer and photolytic rate constant calculation routine, and (3) two chemical 
mechanisms of different complexity. In Refs. $[7,11]$ it is presented an advanced quantumkinetic model to describe the nonlinear-optical (spectroscopic) effect caused by the interaction of infrared laser radiation with a gas atmosphere. The quantitative features of energy exchange in a mixture of $\mathrm{CO}_{2}-\mathrm{N}_{2}-\mathrm{H}_{2} \mathrm{O}$ atmospheric gases of atmospheric gases were determined and can be used in development of new technologies for observing a state of atmosphere. The results of computing the relative absorption coefficient (normalized to linear absorption coefficient) are presented. In Refs. [11,12] it is presented a new generalized approach, including an improved theory of atmospheric circulation in combination with the hydrodynamic model (he Arakawa-Schubert method of calculation of cloud convection and theory of a complex geophysical field is applied to the simulation of heat and air transfer in atmosphere of industrial region. In this paper we present a set of advanced photochemical box models (APBM) with the inclusion of a submodel of the boundary layer using complex plane field methods [2,1316]) and spectral algorithms with optimized blocks describing nonlinear radiation transfer and chemical conversion mechanisms [11,12], quantum-kinetic and photoelectronic models for describing nonlinear optical effects due to the interaction of infrared laser radiation with the gas atmosphere of an industrial city..

\section{An advanced photochemical model}

The APBM is based on the principle of an energy and mass conservation. As in the original version [4], we assume too that (1) the box volume is well mixed at all times and no spatial variations of concentration occur within it; (2) emission sources are homogeneously distributed across the bottom surface of the box; (3) entrainment of outside air occurs laterally by advective transport and vertically by the growth in mixed layer height. Under these assumptions, the chemical species conservation equation becomes:

$$
\begin{aligned}
& \frac{\partial C_{i}}{\partial t}=-u \frac{\partial C_{i}}{\partial x}-\frac{d}{d} \frac{\partial C_{i}}{\partial z}-\frac{Q_{i}}{z}+ \\
& +R_{i}\left(C_{1}, \ldots, C_{n}\right)+F(x, z, t)
\end{aligned}
$$

where $C_{\mathrm{i}}$ is the mean concentration of species "I" within the definite domain, $u$ the mean advection speed, $Q_{\mathrm{i}}$ the source emissions flux of species $\mathrm{i}$ in the domain, and $R_{\mathrm{i}}$ the rate of production and/or destruction of species $i$ due to chemical reactions. The original model by Jin-Schere-Demerjian [4] has a horizontal extension of $20 \mathrm{~km}$ and a vertical extension of the mixed-layer height. Our APBM model has a horizontal extension of $40 \mathrm{~km}$ and less significantly lower resolution (grid scale). A schematic illustration and flowchart of our APBM with the incorporated blocks is shown at Figure 1. The physical features of air ventilation predetermine the necessary modification of the well-known Arakawa-Schubert model. The model includes the budget equations for mass, moist static energy, total water content plus the equations of motion $[2,13]$ :

$$
\begin{gathered}
E-D-\frac{\partial M_{c}}{\partial z}=0 \\
E \tilde{s}-D s_{c}-\frac{\partial M_{c} s_{c}}{\partial z}+p L c=0 \\
E \tilde{q}-D q_{c}-\frac{\partial M_{c} q_{c}}{\partial z}+p c=0
\end{gathered}
$$

where $E$ is an inflow, $D$ is an outflow, $M_{c}=\sum p w_{i} \sigma_{i}=p w_{c} \sigma$ - vertical mass flow of air in the cloud; $w_{\mathrm{i}}$ is an average (on the cross-section) speed in the i-th cloud, $c$ horizontal cross-section square for the $i$-th cloud; $w_{c}, s_{c}=c_{p} T+g z, q_{c}$ is weighted

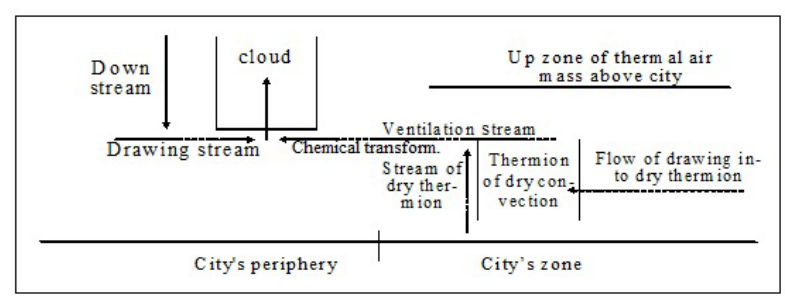

Fig. 1. Flowchart of the APBM with the incorporated blocks 
verage values of vertical speed, statistical energy and the ratio of the mixture of water vapor; $\tilde{s}, \tilde{q}$ - average statistical energy and the ratio of the mixture of water vapor in the ambient air, $p$ air density; $c$ is an amount of the condensed moisture. If $e$ is an amount of evaporated moisture, $L$ - specific heat of phase transitions, then the equation of heat and moisture influx will be as follows $[2,13]$ :

$$
\frac{\partial \overline{p s}}{\partial t}+v \overline{p s \vec{v}}+\frac{\partial \overline{(p w s)}}{\partial z}+p L(c-e)-\frac{\partial \overline{(p w)^{\prime} s^{\prime}}}{\partial z}
$$

$\frac{\partial \overline{p q}}{\partial t}+v \overline{p q \vec{v}}+\frac{\partial \overline{(p w q)}}{\partial z}+p(c-e)-\frac{\partial \overline{(p w)^{\prime} q^{\prime}}}{\partial z} ;$

Spectral representations in ensemble of clouds

$$
\begin{gathered}
\text { are: } \quad E(z)=\int \varepsilon(z, \lambda) m_{B}(\lambda) d \lambda \\
D(z)=\int d(z, \lambda) m_{B}(\lambda) d \lambda
\end{gathered}
$$

If $A$ is a work of the convective cloud then it consists of convection work and work of down falling streams in the neighbourhood of a cloud:

$$
\begin{aligned}
& d A / d t=d A / d t_{\text {conv }}+d A / d t_{\text {downstr }}, \\
& d A / d t_{\text {downstr }}=\int_{0}^{\lambda_{\max }} m_{B}\left(\lambda^{\prime}\right) K\left(\lambda, \lambda^{\prime}\right) d \lambda^{\prime},
\end{aligned}
$$

Here $\lambda$ is a speed of involvement, $m_{B}(\lambda)$ is an air mass flux, $K\left(\lambda, \lambda^{\prime}\right)$ is the Arakawa-Schubert integral equation kernel [3], which determines the dynamical interaction between the neighbours clouds. In the case of air ventilation emergence, mass balance equation in the convective thermals is [13]:

$$
m_{B}(\lambda)=F(\lambda)+\beta \int_{0}^{\lambda_{\max }} m_{B}\left(\lambda^{\prime}\right) K\left(\lambda, \lambda^{\prime}\right) d \lambda^{\prime}
$$

Here $\beta$ is parameter which determines disbalance of cloud work due to the return of part of the cloud energy to the organization of a wind field in their vicinity, and balance regulating its contribution to the synoptic processes. The solution of the Eqs. (3)(-4) with accounting for air stream superposition of synoptic processes is given by a resolvent:

$$
\begin{gathered}
m_{B}(\lambda)=F(\lambda)+\beta \int_{0}^{\lambda_{\max }} F(s) \Gamma(\lambda, s ; \beta) d s, \\
\Gamma(\lambda, s ; \beta)=\sum_{i=1}^{\infty} \beta^{i-1} \cdot K_{i}(\lambda, s)
\end{gathered}
$$

The key idea $[2,13]$ is to determine the resolvent as an expansion to the Laurent series in a complex plane $\zeta$. Its centre coincides with the centre of the city's "heating" island and the internal cycle with the city's periphery. The external cycle can be moved beyond limits of the urban recreation zone. The Laurent representation for resolvent is provided by the standard expansion:

$$
\begin{gathered}
\Gamma=\sum_{n=\infty}^{\infty} c_{n}(\zeta-a)^{n} \\
c_{n}=\frac{1}{2 \pi i} \oint_{|\zeta|=1} \frac{\Gamma(\zeta) d \zeta}{(\zeta-a)^{n+1}}=\frac{1}{2 \pi i} \int_{0}^{2 \pi} \Gamma\left(e^{i t}\right) e^{-i n t} d t
\end{gathered}
$$

where $a$ is center of the Laurent series convergence ring. The method for calculating a turbulence spectra inside the urban zone should be based on solving the system of equations for the Reynolds tensions, moments of connection of the speed pulsations with entropy ones and the corresponding closure equations [2,1317]. The important parameter of the turbulent processes is the kinetic energy of turbulent vortices $b^{2}=\overline{u_{k}^{\prime} u_{k}^{\prime}}$, which can be found from the equation [13]. The speed components, say, $\mathrm{u}_{x}, u_{y}$, of an air flux can be determined in an approximation of "shallow water" [2]. In contrast to the standard difference methods of solution, here we use the spectral expansion algorithms [16]. The necessary solution, for example, for the $v_{x}-i v_{y}$ component for the city's heat island has the form of expansion into series on the Bessel functions. From the other side, a air flux speed over a city's periphery in a case of convective instability can be found by method of plane complex field theory (in analogy with the Karman vortices chain model) [2,13-16]. 


\section{Advanced quantum-kinetic model}

The interaction of laser radiation with a mixture of atmospheric gases, leads to relatively complex processes of resonant excitation transfer, in particular, from $\mathrm{CO}_{2}$ molecules to nitrogen molecules. As a result, the complex dielectric constant of the atmospheric medium will change, which will lead to a significant transformation of the energy of laser pulses in the gas atmosphere [1,3]. The dielectric constant depends on the intensity of the electromagnetic wave $I$ :

$$
\begin{gathered}
\varepsilon=\varepsilon(I)=\bar{\varepsilon}_{0}+\varepsilon_{N}(I) \\
I=\frac{c \sqrt{\varepsilon_{0}}}{8 \pi}|\vec{E}|^{2}
\end{gathered}
$$

where $c$ is the speed of light, $E$ is the electric field strength of the wave. When laser radiation interacts with atoms and molecules of atmospheric gases, there is also the so-called Kerr electronic effect, which arises due to the deformation of the electron density distributed by the field, almost immediately following the change of field, as well as the orientation effect of Kerr [3]. The relaxation time of this effect for atmospheric air under normal conditions is $10^{-13}$ s. This effect leads to the dependence of the dielectric constant on the field of the electromagnetic wave in the formula (11) of the form

$$
\varepsilon_{N}=\varepsilon_{2}|E|^{2} .
$$

For Gaussian beams and plateau beams, the Kerr effect leads to the self-focusing of light, described in detail, for example, in $[3,8,9,11]$. If the length of the nonlinear interaction (selffocusing) is a Gaussian beam with radius $R_{0}$

$$
L_{N}=\frac{R_{0}}{\sqrt{\varepsilon_{2}|E|^{2}}}=R_{0}\left(\frac{8 \pi \varepsilon_{2}}{c \sqrt{\varepsilon_{0}}} I\right)^{-1 / 2},
$$

then the realization of the effect on distance $L_{\|}$is possible if the threshold intensity is defined [3]:

$$
I_{\ddot{I} \hat{D}} \geq \frac{c \sqrt{\varepsilon_{0}}}{8 \pi} \frac{R_{0}^{2}}{\varepsilon_{2} L_{\|}^{2}} .
$$

$I_{\text {THR }} \sim 10^{10} \mathrm{~W} \cdot \mathrm{cm}^{-2}$ for $R_{0}=0.1$ and $L_{\|}=10^{3}$ m. If $L_{\|}=10^{5} \mathrm{~m}$, then $I_{T H R} \sim 10^{8} \mathrm{~W} \cdot \mathrm{cm}^{-2}$. For infrared laser wavelength $\lambda=10.6 \mu \mathrm{m}$, the critical autofocus $\left(L_{\|}=L_{d}\right)$ power is:

$$
P_{\hat{e} \delta}=\pi R_{0}^{2} I_{\ddot{I} \hat{I}}=\frac{c \sqrt{\varepsilon_{0}}}{8 k^{2} \varepsilon_{2}}=1,7 \cdot 10^{11}
$$

One finds $P_{\hat{e} \delta}=1,7 \cdot 10^{9} \mathrm{~W}$ for $\lambda=1,06 \mu \mathrm{m}$.

Further let us present an advanced quantumkinetic model to describe the nonlinear-optical (spectroscopic) effect caused by the interaction of infrared laser radiation with a gas atmosphere and consider the quantitative features of energy exchange in a mixture of $\mathrm{CO}_{2}-\mathrm{N}_{2}-\mathrm{H}_{2} \mathrm{O}$ atmospheric gases of atmospheric gases. The original version was presented in Refs. [11,12].

Typically, for the quantitative description of energy exchange and the corresponding relaxation processes in a mixture of $\mathrm{CO}_{2}-\mathrm{N}_{2}-\mathrm{H}_{2} \mathrm{O}$ gases in the laser radiation field, one should first consider the kinetics of three levels: $10^{\circ} 0,00^{\circ} 1$ $\left(\mathrm{CO}_{2}\right)$ i v $=1\left(\mathrm{~N}_{2}\right)$. The system of differential equations of balance for relative populations is written in the following form:

$$
\begin{aligned}
& \frac{d x_{1}}{d t}=-\beta\left(\omega+2 g P_{10}\right) x_{1}+\beta \omega x_{2}+ \\
& \left.+2 \beta g P_{10}\right) x_{1}^{0}+F_{N}\left(x_{1}\right) \\
& \frac{d x_{2}}{d t}=\omega x_{1}-\left(\omega+Q+P_{20}\right) x_{2}+ \\
& +Q x_{3}+P_{20} x_{2}^{0}+F_{N}\left(x_{2}\right), \\
& \frac{d x_{3}}{d t}=\delta Q x_{2}-\left(\delta Q+P_{30}\right) x_{3}+ \\
& P_{30} x_{3}^{0}+F_{N}\left(x_{3}\right)
\end{aligned}
$$

Here, $x_{1}=N_{100} / N_{\mathrm{CO}_{2}}, \quad x_{2}=N_{001} / N_{\mathrm{CO}_{2}}, \quad x_{3}$ $=\delta N_{\mathrm{N}_{2}} / N_{\mathrm{CO}_{2}} ; N_{100}, N_{001}$ are the level populations $10^{\circ} 0, \quad 00^{\circ} 1 \quad\left(\mathrm{CO}_{2}\right) ; \quad N_{\mathrm{CO}_{2}}$ is concentration of $\mathrm{CO}_{2}$ molecules; $N_{\mathrm{N}_{2}}$ is the level 
population $\mathrm{v}=1\left(\mathrm{~N}_{2}\right) ; Q$ is the probability $\left(\mathrm{s}^{-1}\right)$ of resonant transfer in the reaction $\mathrm{CO}_{2} \rightarrow \mathrm{N}_{2}, \omega$ is a probability $\left(\mathrm{s}^{-1}\right)$ of $\mathrm{CO}_{2}$ light excitation, $g=3$ is statistical weight of level $02^{\circ} 0, \quad \beta=(1+g)^{-1}=$ $1 / 4 ; \delta$ is ratio of common concentrations of $\mathrm{CO}_{2}$ and $\mathrm{N}_{2}$ in atmosphere $\left(\delta=3.85 \times 10^{-4}\right) ; F_{N}(x)-$ additional nonlinear term; $x_{1}^{0}, x_{2}^{0}$ and $x_{3}^{0}$ are the equilibrium relative values of populations under gas temperature $T$ :

$$
\begin{aligned}
& x_{1}^{0}=\exp \left(-E_{1} / T\right), \\
& x_{2}^{0}=x_{3}^{0}=\exp \left(E_{2} / T\right)
\end{aligned}
$$

Values $E_{1}$ and $E_{2}$ in (1) are the energies (K) of levels $10^{\circ} 0,00^{\circ} 1$ (consider the energy of quantum $N_{2}$ equal to $\left.E_{2}\right) ; P_{10}, P_{20}$ and $P_{30}$ are the probabilities $\left(\mathrm{s}^{-1}\right)$ of the collisional deactivation

of levels $10^{\circ} 0,00^{\circ} 1\left(\mathrm{CO}_{2}\right)$ and $\mathrm{v}=1\left(\mathrm{~N}_{2}\right)$.

Note that having obtained the solution of the differential equation system (17), one can further calculate the absorption coefficient of radiation by $\mathrm{CO}_{2}$ molecules:

$$
\alpha_{\mathrm{CO}_{2}}=\sigma\left(x_{1}-x_{2}\right) N_{\mathrm{CO}_{2}} .
$$

The $\sigma$ in Eq. (20) is dependent upon the thermodynamical medium parameters according to [1]. The different estimates (c.g., [3,11]) show that for emission of the $\mathrm{CO}_{2}$-laser the absorption coefficient:

$$
\alpha_{g}=\alpha_{\mathrm{CO}_{2}}+\alpha_{\mathrm{H}_{2} \mathrm{O}}
$$

is equal in conditions, which are typical for summer mid-latitudes $\alpha_{\mathrm{g}}[\mathrm{H}=0]=(1.1-2.6) \cdot 10^{6}$ $\mathrm{cm}^{-1}$, from which $0.8 \cdot 10^{6} \mathrm{~cm}^{-1}$ accounts for $\mathrm{CO}_{2}$ and the rest - for water vapour (data are from ref. [3]) . The resonance absorption by the molecules of the atmospheric mixture of laser radiation is determined by the change in the population of the low-lying level $10^{\circ} 0\left(\mathrm{CO}_{2}\right)$, the population of the level $00^{\circ} 1$ and vibration-translational relaxation (VT-relaxation), as well as intergenerational vibration relaxation (VV'-relaxation). For the wavelength of infrared laser radiation (eg, $\mathrm{CO}_{2}$ laser of $10.6 \mu \mathrm{m}$ ), the duration of the corresponding pulse will satisfy the inequality $t_{R} \ll t_{i}<$
$t_{V T}$, where $t_{R}, t_{V T}$ are the values of time, respectively, of rotational and oscillatory relaxation. In Ref. [12] there are presented the results of an accurate numerical calculations with using the accurately determined probabilities of $P_{10}, P_{20}$ , $P_{30}$ of deactivation due to the levels of $10^{\circ} 0$, $00^{\circ} 1\left(\mathrm{CO}_{2}\right)$ and $\mathrm{v}=1\left(\mathrm{~N}_{2}\right)$, the probability of $\mathrm{Q}$ resonance energy transfer $\mathrm{CO}_{2} \rightarrow \mathrm{N}_{2}$, the excitation probability $\omega$ pulse of $\mathrm{CO}_{2}$ laser and other constants. The results of computing the relative

absorption coefficient $\bar{\alpha}_{\mathrm{O}_{2}}$ (normalized to linear absorption coefficient) based on the solutions of the system (17) have been presented for the distribution of pressure altitude and temperature within the model of atmosphere of the middle latitudes (Odessa) $[2,13]$. It is clear that the time dependence of the relative resonance absorption coefficient of laser radiation by $\mathrm{CO} 2$ molecules for different laser pulses differs. Using these data we determine that the effect of kinetic cooling of the $\mathrm{CO}_{2}$ is determined by the condition (for Odessa region):

$$
\alpha_{\mathrm{H}_{2} \mathrm{O}}^{0}<\left(E_{1} /\left(E_{2}-E_{1}\right)\right) \alpha_{\mathrm{CO}_{2}}^{0}=1.51 \alpha_{\mathrm{CO}_{2}}^{0}
$$

Note that Eq. (22) is sufficiently significantly different from early qualitative estimates $[3,11]$. The numerical parameters obtained allow us to further quantify the effects of the kinetic cooling of $\mathrm{CO}_{2}$, depending on the parameters of the model of the atmosphere and the parameters of laser radiation [3].

\section{Conclusions}

To conclude, we presented an advanced photochemical box model with the incorporation of a boundary-layer complex plane field submodel [2,13-17], advanced quantum-kinetic and photoelectronic models to describe the nonlinearoptical (spectroscopic) effect caused by the interaction of infrared laser radiation with a gas atmosphere, and an advanced nonlinear radiative transfer and chemical mechanisms blocks. From physical viewpoint, it is clear that because of the resonant interaction (in particular, absorption) of electromagnetic radiation with atmo- 
spheric molecular gases there is the quantitative redistribution of molecules by the energy levels of internal degrees of freedom. The radiative and energy flux that causes the gas to be heated through the absorption by the water vapour, is proportional to the intensity of the laser radiation. When the critical value is reached, the heating of the steam will prevail over its cooling for any moment of time. In such a physical situation, the effect of kinetic cooling will cease to exist. The quantitative manifestation of the kinetic effect may vary for different atmospheric conditions, laser radiation parameters, and different values of atomic-molecular parameters.

\section{References}

1. Gubanova E.R., Glushkov A.V., Khetselius O.Yu., Bunyakova Yu.Ya., Buyadzhi V.V., Pavlenko E.P., New methods in analysis and project management of environmental activity: Electronic and radioactive waste. FOP: Kharkiv, 2017.

2. Bunyakova, Yu.Ya.; Glushkov, A.V. Analysis and forecast of the impact of anthropogenic factors on air basein of an industrial city. Ecology: Odessa, 2010.

3. Zuev V., Zemlyanov A., Kopytin Y., Kuzikovsky A The laser radiation in atmospheric aerosol. Novosybirsk, 1984

4. Jin, S., Demerjian, K. A photochemical box model for urban air quality study. Atm. Envir.B. Urban Atm. 1993, 27, 371

5. Glushkov, A., Safranov, T., Khetselius, O., Ignatenko, A., Buyadzhi, V., Svinarenko, A. Analysis and forecast of the environmental radioactivity dynamics based on methods of chaos theory: General conceptions. Environm. Problems. 2016, 1(2), 115-120.

6. Khetselius, O. Optimized perturbation theory for calculating the hyperfine line shift and broadening of heavy atoms in a buffer gas. Frontiers in quantum methods and applications in Chem. and Phys.; Cham: Springer, 2015, 29, 55-76.

7. Glushkov, A., Buyadzhi, V., Kvasikova, A., Ignatenko, A., Kuznetsova, A., Prepelitsa G., Ternovsky, V. Non-linear chaotic dy- namics of quantum systems: Molecules in an electromagnetic field and laser systems. In: Quantum Systems in Physics, Chemistry, and Biology. Springer, Cham. 2017, 30, 169-180

8. Gordiets B., Osipov A.I., Kokhlov R. About cooling gas under powerful $\mathrm{CO}_{2}$ laser radiation passing in atmosphere. J. Tech. Phys. 1974, 14, 1063-1066.

9. Geints Y., Zemlyanov A. Near- and mid-IR ultrashort laser pulse filamentation in a molecular atmosphere: a comparative analysis. Appl. Opt. 2017, 56, 1397.

10. Wei, P.-S., Hsieh, Y.-C., Chiu, H.-H., Yen, D.-L., Lee, C., Tsai, Y.-C., \& Ting, T.-C. Absorption coefficient of carbon dioxide across atmospheric troposphere layer. Heliyon. 2018, 4(10), e00785.

11. Glushkov A.V., Serbov N.G., Bunyakova Yu.Ya., Prepelitsa G.P., Svinarenko A.A. Sensing the kinetical features of energy exchange in mixture $\mathrm{CO}_{2}-\mathrm{N}_{2}-\mathrm{H}_{2} \mathrm{O}$ of atmospheric gases under interacting with laser radiation. Sensor Electr. and Microsyst. Techn. 2006. N4. P.20-22.

12. Bunyakova, Yu.Ya., Glushkov, A.V., Khetselius, O.Yu., Svinarenko, A.A., Ignatenko, A.V., Bykowszczenko, N. Modeling of nonlinear optical effects in the interaction of laser radiation with atmosphere and sensing for energy exchange in a mixture atmospheric gases. Sensor Electr. and Microsyst. Techn. 2019, 16(3), 42-50.

13. Sofronkov A, Khetselius O, Glushkov A, Buyadzhi V, Romanova A., Ignatenko A. New geophysical complex-field approach to modelling dynamics of heat-mass-transfer and ventilation in atmosphere of the industrial region. Phys. Aerodisp. Syst. 2018, 55, 104-111

14. Glushkov, A.V., Svinarenko, A.A., Khetselius, O., Serbov, N. The sea and ocean 3D acoustic waveguide: rays dynamics and chaos phenomena. J. Acoust. Soc. America. 2008, 123, 3625.

15. Serbov N.G., Svinarenko A.A. Wavelet and multifractal analysis of oscillations in system of couled autogenerators in chaotic regime. Photoelectr. 2006, 15, 27 
16. Glushkov A.V., Khetselius O.Yu., Svinarenko A.A., Buyadzhi V.V., Methods of computational mathematics and mathematical physics. P.1. TES: Odessa, 2015.
17. Khetselius, O. Forecasting evolutionary dynamics of chaotic systems using advanced non-linear prediction method. Dynamical Systems Applications; Lodz Univ.: Lodz. 2013, T2, 145-152.

PACS 64.60.A+82.70.R

O. Yu. Khetselius, A. V. Glushkov, S. N. Stepanenko, A. A. Svinarenko,

Yu. Ya. Bunyakova, E. T. Vitovskaya

\section{ADVANCED PHOTOCHEMICAL BOX AND QUANTUM-KINETIC MODELS FOR SENSING ENERGY, RADIATION EXCHANGE IN ATMOSPHERIC GASES MIXTURES AND LASER- MOLECULES INTERACTION}

Summary. The aim of the work is to develop a set of optimal photochemical models with the inclusion of a submodel of the boundary layer using complex plane field methods and spectral algorithms and optimized blocks describing nonlinear radiation transfer and chemical conversion mechanisms, quantum-kinetic and photoelectronic models for describing nonlinear optical effects due to the interaction of infrared laser radiation with the gas atmosphere of industrial city. The resonant interaction of electromagnetic radiation with molecular gases leads to redistribution of molecules by energy levels of freedom internal degrees, which changes the gas absorption coefficient. A change in the population levels causes a violation of thermodynamic equilibrium between the vibrations of molecules and their translational motion, providing a new nonlinear effect of the photokinetic cooling of atmosphere.

Key words: energy exchange kinetics, atmospheric gases, laser radiation, photochemical model, quantum kinetic model

PACS 64.60.A+82.70.R

О. Хецелиус, А. Глушков, С. Степаненко, А. Свинаренко, Ю. Бунякова, Е. Витовская

\section{ОПТИМАЛЬНЫЕ ФОТОХИМИЧЕСКАЯ И КВАНТОВО-КИНЕТИЧЕСКАЯ МОДЕЛИ ДЛЯ ДЕТЕКТИРОВАНИЯ ЭНЕРГО-РАДИАЦИОННО-ОБМЕННЫХ ПРО- ЦЕССОВ В СМЕСИ АТМОСФЕРНЫХ ГАЗОВ И ВЗАИМОДЕЙСТВИЯ ЛАЗЕРНОГО ИЗЛУЧЕНИЯ С АТМОСФЕРНЫМИ МОЛЕКУЛАМИ}

Резюме. Цель работы состоит в разработке комплекса оптимальной фотохимической модели (с включением субмодели пограничного слоя и использованием методов комплексного плоского поля) и спектральных моделей с оптимизированными блоками, описывающими нелинейный перенос излучения и химические преобразовательные механизмы, квантовокинетической и фотоэлектронной моделей для описания нелинейно-оптических эффектов, обусловленных взаимодействием инфракрасного лазерного излучения с газовой атмосферой промышленного города. Резонансное взаимодействия электромагнитного излучения с молекулярными газами атмосферы приводит к количественному перераспределению молекул по энергетическим уровням внутренних степеней свободы, что изменяет называемый коэффициент поглощения газа. Изменение уровней заселенности смеси газов вызывает нарушение 
термодинамического равновесия между колебаниями молекул и их поступательным движением и обуславливает новый нелинейный эффект фотокинетического охлаждения атмосферной среды.

Ключевые слова: кинетика энергообмена, атмосферные газы, лазерное излучение, фотохимическая модель, квантово-кинетическая модель

PACS 64.60.A+82.70.R

О. Хеиеліус, О. Глушков, С. Степаненко, А. Свинаренко, Ю. Бунякова, О. Вітовська

\section{ОПТИМАЛЬНІ ФОТОХІМІЧНА І КВАНТОВО-КІНЕТИЧНА МОДЕЛІ ДЛЯ ДЕТЕКТУВАННЯ ЕНЕРГО-РАДІАЦІЙНО-ОБМІННИХ ПРОЦЕСІВ В СУМІШІ АТМОСФЕРНИХ ГАЗІВ І ВЗАЕМОДІЇ ЛАЗЕРНОГО ВИПРОМІНЮВАННЯ $З$ АТМОСФЕРНИМИ МОЛЕКУЛАМИ}

Резюме. Мета роботи полягає в розробці комплексу оптимальної фотохімічної моделі (з включенням субмоделі прикордонного шару і використанням методів комплексного плоского поля) і спектральних моделей з оптимізованими блоками, що описують нелінійний перенос випромінювання і хімічні перетворюючі механізми, квантово-кінетичної і фотоелектронної моделей для опису нелінійно-оптичних ефектів, обумовлених взаємодією інфрачервоного лазерного випромінювання з газової атмосферою промислового міста. Резонансна взаємодія електромагнітного випромінювання з молекулярними газами атмосфери веде до кількісного перерозподілу молекул по енергетичним рівням внутрішніх ступенів свободи, що змінює званий коефіцієнт поглинання газу. Зміна рівнів заселеності суміші газів викликає порушення термодинамічної рівноваги між коливаннями молекул і їх поступальним рухом і обумовлює новий нелінійний ефект фотокінетичного охолодження атмосферного середовища.

Ключові слова: кінетика енергообміну, атмосферні гази, лазерне випромінювання, фотохімічна модель, квантово-кінетична модель 